\title{
Liver and body mass gain, content of conjugated linoleic acid (CLA) isomers and other fatty acids in the liver of rats fed CLA isomers and selenium*
}

\section{Czauderna ${ }^{1,3}$, J. Kowalczyk ${ }^{1}$, K.M. Niedźwiedzka ${ }^{1}$, I. Wąsowska ${ }^{1}$, B. Pastuszewska ${ }^{1}$, E. Bulska ${ }^{2}$ and A. Ruszczyńska ${ }^{2}$}

\author{
${ }^{I}$ The Kielanowski Institute of Animal Physiology and Nutrition, \\ Polish Academy of Sciences \\ 05-110 Jabłonna, Poland \\ ${ }^{2}$ Faculty of Chemistry, Warsaw University \\ Pasteura 1, 02-093 Warsaw, Poland
}

(Received 25 February 2004; accepted 9 April 2004)

\begin{abstract}
The influence of selenium (as $\mathrm{Na}_{2} \mathrm{SeO}_{4}$ ) and/or conjugated linoleic acid isomers (CLA) on relative body mass gain of rats, liver weight, concentrations of CLA isomers and of other fatty acids in the rat liver were investigated. Feeding selenium (Se) and/or CLA resulted in small changes in the relative body mass and liver mass gain of rats. The administered CLA isomers significantly elevated the concentration of CLA isomers and non-CLA fatty acids containing conjugated double bonds (CFA) in the liver. Addition of Se to a diet enriched in CLA isomers generally stimulated the accumulation of CLA isomers and CFA in the liver. Our results demonstrate that the trans-trans CLA isomers are catabolized more slowly and are poor substrates for $\beta$-oxidation. The cis-trans/trans-cis CLA isomers are rapidly metabolized to form longer-chain fatty acids containing conjugated double bonds, and are partly $\beta$-oxidized. Dietary supplementation to $1 \%$ of a mixture of CLA isomers or individual CLA isomers, regardless of the presence of Se in the diets, resulted in a reduction of the sum of all assayed fatty acids, saturated fatty acids (SFA), PUFA and MUFA. Our study demonstrated that dietary CLA isomers, regardless of the presence $\mathrm{Se}$ in the diet, caused a reduction in $\Delta 9$-desaturase capacity, inhibited steaoryl-CoA desaturase mRNA expression, and fatty acid synthesis. As a result, the value of the concentration ratio of oleic acid to $\mathrm{C} 18: 0$ (i.e. $\mathrm{R}_{\mathrm{C} 18: 0 / \text { leic acid }}-\Delta$ 9-desaturase index) in the liver of rats fed the experimental diets increased.
\end{abstract}

KEY WORDS: liver, CLA, selenium, fatty acids, rats

\footnotetext{
* Supported in part by the State Committee for Scientific Research, Grant No. 3 Po6Z 03422

${ }^{3}$ Corresponding author: e-mail: m.czauderna@ifzz.pan.pl
} 


\section{INTRODUCTION}

Conjugated linoleic acids (CLA) are a group of geometric (trans, trans, cis, cis, cis,trans, trans,cis) and positional (7-9, 8-10, 9-11, 10-12, 11-13) isomers of conjugated octadecadienoic acid. There is increasing interest in commercializing CLA as a health supplement and as a food ingredient because some CLA isomers are anticarcinogenic in experimental animals, as well as hypolipidaemic or antiatherosclerotic (Szymczyk et al., 2000; Yang et al., 2002). Recent data obtained in mice (Alasnier et al., 2002) and rats (Czauderna et al., 2003b) suggest that CLA supplementation reduced adipose tissue by apoptosis, developed lipodystrophy, improved both body mass gain and feed conversion efficiency (Szymczyk et al., 2000; Czauderna et al., 2003b; Nagao et al., 2003), and may also enhance immune function (Yang et al., 2002). Recent investigations have demonstrated that the cis-9,trans-11 CLA isomer is associated with anti-carcinogenic properties in humans and in experimental mice and rats (Gnädinget et al., 2001; Corino et al., 2002; Degrace et al., 2003). On the other hand, the trans-10,cis-12 isomer has antiobesity activity. These effects were achieved through decreased body fat accretion and cholesterol ester synthesis and by reduced hepatocytic apolipoprotein B secretion. These effects were supported by a specific reduction in lipoprotein lipase activity, adipocyte cells levels of intracellular triglycerol and glycerol, and by increased lipolysis in adipocytes (Simon et al., 2000). The $t 10, c 12$ CLA isomer inhibits the activity and gene expression of $\Delta 9$-desaturase (Madron et al., 2002; Czauderna et al., 2004), thereby reducing endogenous synthesis of the $c 9, t 11$ CLA isomer. West et al. (1998) and Czauderna et al. (2003b) suggested that CLA supplemented to a diet elevated liver mass as well as spleen, heart and pancreas mass. The increased liver mass of mice fed CLA is probably due to lipid accumulation because this has been found in dietary experiments, including body mass loss, or manipulations of dietary fat and protein composition (West et al., 1998). Moreover, the study by Sakono et al. (1999) demonstrated that CLA influenced fatty acid (FA) metabolism, i.e. in the liver, including accelerating $\beta$-oxidation in the liver of rats fed CLA (Alasnier et al., 2002; Degrace et al., 2003; Nagao et al., 2003).

That selenium was essential in nutrition was recognized in the late 1950's when it was found that Se was a component of liver glutathione peroxidases (cGPx) and could replace vitamin $\mathrm{E}$ for prevention of hepatic lesions in rats (Tapiero et al., 2003). The possibility that dietary Se may decrease cancer risk might be expected on the basis of higher expression of selenoenzymes (e.g., hepatic cGPx) involved in antioxidant protection, and redox regulation (thioredoxin reductases) (Wolffram, 1999; Arteel and Sies, 2001; Tapiero et al., 2003). In several studies on rats it was found that the concentration of polyunsaturated fatty acids (PUFA) was positively correlated with the level of Se in diets (Crespo et al., 1995). Phospholipid hydroperoxide cGPx in particular interacted more directly than cytosolic 
and mitochondrial cGPx in protecting PUFA from peroxidation damage (Crespo et al., 1995).

The purpose of the present study was to establish the bioavailability of individual CLA isomers and their mixture, and the extent to which dietary Se (as sodium selenate) may change the isomer content in the liver of rats. Another aim was to investigate the influence of exposure to CLA isomers and/or Se on the composition of other fatty acids in the rat liver.

\section{MATERIAL AND METHODS}

\section{Animals and experimental design}

Ten groups of female rats (Wistar, Ifz: BOA), 8 weeks of age and an initial body mass about $200 \mathrm{~g}$ were housed individually in plastic cages as described in our previous publication (Czauderna et al., 2004). Briefly, during a 1-week preliminary period the animals were fed a standard Labofeed diet (Se content less than $0.1 \mathrm{ppm}$ ) given at a submaintenance level (daily $\sim 9 \mathrm{~g}$ of the diet per rat) to reduce their body fat content (Table 1). Then they were fed ad libitum the Labofeed diet enriched in a mixture of CLA isomers, the cis-9,trans-11 CLA isomer $(c 9, t 11)$, or trans-10, cis-12 CLA isomer $(t 10, c 12)$ and/or Se (as sodium selenate) (Table 1). After the four-week experimental period the rats were killed, the livers were removed and weighed.

\section{Chemicals and analytical methods}

All of the reagents used, the methods of hydrolysis (Czauderna and Kowalczyk, 2001) and derivatization (Czauderna et al., 2002), and HPLC configurations were as previously described (Czauderna et al., 2004). The underivatized CLA isomers and other fatty acids (FA) containing conjugated double bonds (CFA) were determined according to Czauderna et al. (2003a) ( $\mathrm{Ag}^{+}$-HPLC system A), while the derivatized CLA isomers and other FA in liver samples were determined according to Czauderna and Kowalczyk (2002) (HPLC system B). Selenium (via $\mathrm{Se}^{82}$ ) and zinc (via $\mathrm{Zn}^{64}$ ) in the liver were determined by the CPI-MS method after sample digestion using a mixture of $65 \% \mathrm{HNO}_{3}$ and $30 \% \mathrm{H}_{2} \mathrm{O}_{2}(2: 1, \mathrm{v} / \mathrm{v})(\mathrm{Wy}-$ socka et al., 2003).

\section{Statistical analyses}

The data are presented as means. Statistical analyses of the effects of Se or the CLA isomers in the diets were conducted using the non-parametric Mann- 


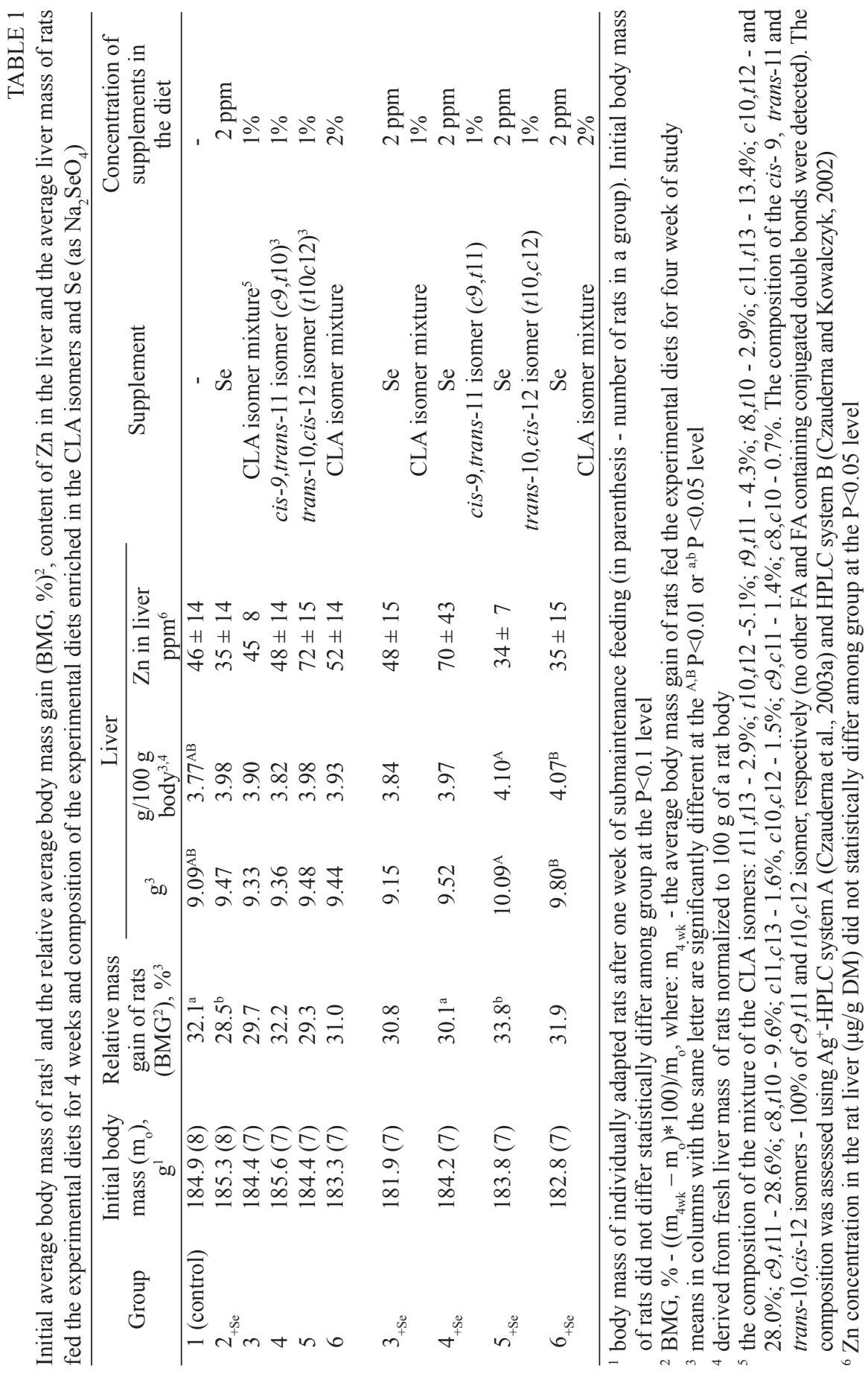


Whitney $U$ test for comparing independent experimental groups, while statistical analyses of the interaction between the CLA isomers and Se (Groups $3_{+\mathrm{Se}}, 4_{+\mathrm{Se}}$, $5_{+\mathrm{Se}}$ and $6_{+\mathrm{Se}}$ ) were performed using two-way analysis for comparison with the independent control group 1. The Statistica ver. 6 and Excel 2000 programs were applied for the statistical analyses.

\section{RESULTS AND DISCUSSION}

The influence of dietary the CLA isomers and Se on relative body mass gain and liver mass

Experimental data affecting concentrations of zinc in the liver of rats fed the experimental diets are summarized in Table 1. No lesions or symptoms of Se and CLA isomer intoxication were found in rats fed experimental diets. We found that the experimental diets had no consistent influence on the concentration of $\mathrm{Zn}$ in the rat liver. The diet enriched in $2 \mathrm{ppm}$ of Se would not be toxic for rats because only chronic feeding of inorganic Se compounds at a rate of more than $5 \mathrm{ppm}$ can be hepatotoxic and teratogenic in animals and humans (Tapiero et al., 2003). Indeed, $\mathrm{LD}_{50}$ is about $5 \mathrm{mg} / \mathrm{kg}$ of body mass for rats, so, this correspond with a diet enriched in $\sim 50 \mathrm{ppm}$ Se (i.e. $20 \mathrm{~g}$ this diet per rat and day). Moreover, in contrast to selenide and selenite, selenate is not as effectively incorporated into the body of animals and, fortunately, is less reactive and toxic; it combines with the thiol group of biologically important peptides, proteins, and enzymes after reduction to selenite.

In the current study, it has been shown that the body mass gain of rats fed the mixture of CLA isomers or the $t 10, c 12$ CLA isomer tended to decrease compared with the control rats (Table 1). Unexpectedly, the diet enriched only in Se most efficiently reduced the relative body mass gain of rats, probably due to the negative effect of the high (2 ppm) Se content in the diet on rat growth. Inclusion of the CLA isomers diminished the negative effect of dietary Se on the relative body mass gain (BMG) of rats. The interaction between Se and the $t 10, c 12$ CLA isomer (Group $5_{+\mathrm{Se}}$ ) most efficiently stimulated the relative BMG of rats $(\mathrm{P}<0.05)$ as well as that of liver mass $(\mathrm{P}<0.01)$ (Table 1$)$. Regardless of the presence of Se, all of the experimental diets tended to increase the liver mass of rats. Alasnier et al. (2002), Czauderna et al. (2003b) and Degrace et at. (2003) reported that feeding rats or mice a diet supplemented with CLA isomers increases FA $\beta$-oxidation in the fat pad and skeletal muscles but not in the liver. The physiological responses to CLA in diets for rats suggest modulation of eicosanoid metabolism followed by elongation and $\Delta 5$-desturation in the rat liver (Gnädig et al., 2001). Our data are consistent with these findings, so, feeding 
the mixture of CLA isomers or the $t 10, c 12$ CLA isomer, especially simultaneously with Se, increased liver mass probably due to accumulation of FA metabolites in this organ (Table 4). A recent study (Simon et al., 2000) has clearly shown that in the liver of animals fed the CLA isomers, the fatty acid content is reduced while the protein content in the liver is increased. Another study also indicates that feeding the $t 10, c 12$ CLA isomer resulted in dramatic enlargement of the liver (Degrace et al., 2003). Indeed, at the peroxisomal level, considerable proliferation of small peroxisomes takes place together with increased capacity for $\beta$-oxidation of long-chain FA (Terpsta et al., 2003). At the mitochondrial level, a greater part of activated fatty acids was directed from triacylglycerol esterification towards oxidation.

\section{The influence of the diets on the composition of CLA isomers in liver fat}

The current study also investigated the relationship between the experimental diets and the content and profile of CLA isomers in the liver. As expected, diets with or without Se supplemented with the mixture of CLA isomers or with individual isomers resulted in a significant increase $(\mathrm{P}<0.01)$ in the concentration of CLA isomers in the liver (Table 2) compared with the control rats (Group 1) and rats fed the diet enriched in Se only (Group $2_{+\mathrm{Se}}$ ). Our results (Table 3) support the recent observation of Yang et al. (2002) that liver lipids preferentially accumulated (Groups 3 and 6 ) the trans, trans $(t, t)$ CLA isomers ( 23.4 and $22.2 \%$ of the total amount of the CLA isomers, respectively), as compared with the percentage contribution of the $t, t$ CLA isomers (15.2\%) in the dietary mixture of the CLA isomers. Moreover, detailed analysis of chromatograms revealed that the profile of the $t, t$ CLA isomers in the liver considerably differed from the profile of the positional configuration of the dietary $t, t$ CLA isomers. These results clearly indicate that some CLA isomers or some FA were metabolized to form the $t, t$ CLA isomers. Our experiment demonstrated that the dietary $t, t$ CLA isomers are preferentially metabolized in comparison with the metabolism of the dietary $c, c$ or $c 9, t 11$ and $t 10, c 12$ CLA isomers (Table 3). Consequently, the percentage contribution of the original $t, t$ CLA isomers in the liver is only $9.7-10.1 \%$ of the total amount of CLA isomers in the liver (Groups 3 and 6), whereas they constituted $15.2 \%$ of the $t, t$ CLA isomers in the dietary mixture of the CLA isomers. Feeding the diet enriched in the mixture of CLA isomers and Se (Groups $3_{+\mathrm{Se}}$ and $6_{+\mathrm{Se}}$ ) resulted in only a slightly higher percentage contribution of total $t, t$ CLA isomers $(25.1$ and $25.6 \%$ ) in the liver compared with the percentage contribution of the total $t, t$ CLA isomers in the liver (23.4-22.2\%) of rats fed only the mixture of the CLA isomers (Groups 3 and 6). Detailed analysis of chromatograms shows that the percentage contribution of the dietary $t, t$ CLA isomers in the liver of rats fed CLA 
TABLE 2

Content of total CLA isomers ( $\Sigma$ CLA isomers), individual CLA isomers ( $c 9, t 11$ and $t 10, c 12$ isomers) and the sum of other non-CLA fatty acids containing conjugated double bonds (i.e. $\sum$ CFA) in the liver $(\mu \mathrm{g} / \mathrm{g})^{1}$ of rats fed the experimental diets $^{2}$

\begin{tabular}{|c|c|c|c|c|}
\hline Group & $\begin{array}{l}\text { ¿CLA } \\
\text { isomers }^{3}\end{array}$ & $\sum \mathrm{CFA}^{4}$ & $\begin{array}{c}c 9, t 11 \\
\text { CLA isomer }\end{array}$ & $\begin{array}{c}t 10, c 12 \\
\text { CLA isomer }\end{array}$ \\
\hline 1 & 67.1 & $157.8^{\mathrm{ABCDEFabc}}$ & $42^{\mathrm{ABCDEFabc}}$ & $26^{\mathrm{ABCDEFGH}}$ \\
\hline $2_{+\mathrm{Se}}$ & 75.8 & $1209.0^{\mathrm{aH}}$ & $24^{\mathrm{GHIJa}}$ & $25^{\mathrm{IKLj}}$ \\
\hline 3 & $2600^{a}$ & $478.6^{\mathrm{AG}}$ & $1388^{\mathrm{AK}}$ & $1084^{\mathrm{AM}}$ \\
\hline 4 & 2603 & $280.8^{\text {bd }}$ & $2708^{\mathrm{B}}$ & $70^{\mathrm{Ba}}$ \\
\hline 5 & 2904 & $237.4^{\mathrm{c}}$ & $61^{\mathrm{b}}$ & $3188^{\mathrm{C}}$ \\
\hline 6 & $9622^{\mathrm{ab}}$ & $2206.6^{\mathrm{BG}}$ & $3591^{\mathrm{CK}}$ & $2559^{\mathrm{DM}}$ \\
\hline $3_{+\mathrm{Se}}$ & 2854 & $509.7^{\mathrm{C}}$ & $1788^{\mathrm{DG}}$ & $1490^{\mathrm{EI}}$ \\
\hline $4_{+\mathrm{Se}}$ & 2980 & $1384.3^{\mathrm{Dd}}$ & $3623^{\mathrm{EH}}$ & $165^{\mathrm{Fja}}$ \\
\hline $5_{+\mathrm{Se}}$ & 2710 & $1534.4^{\mathrm{E}}$ & $106^{\mathrm{cI}}$ & $2865^{\mathrm{GK}}$ \\
\hline $6_{+\mathrm{Se}}$ & $7991^{\mathrm{b}}$ & $4336.6^{\mathrm{FH}}$ & $2652^{\mathrm{FJ}}$ & $2159^{\mathrm{HL}}$ \\
\hline
\end{tabular}

${ }^{1}$ specie concentrations were calculated from lyophilized liver samples (i.e. $\mu \mathrm{g} / \mathrm{g}$ )

${ }^{2}$ means in columns with the same letter are significantly different at ${ }^{\mathrm{A}, \mathrm{B}} \mathrm{P}<0.01$ or at ${ }^{\mathrm{a}, \mathrm{b}} \mathrm{P}<0.05$ level

${ }^{3}$ all diets supplemented with the mixture of the CLA isomers or the mixture of the CLA isomer supplemented diets enriched in Se significantly increased CLA isomers content in the liver compared with the control rats (Group 1) and the Se supplemented diet (Group $2_{+\mathrm{Se}}$ ) (the significant difference at the $\mathrm{P}<0.01$ level)

${ }^{4}$ all diets supplemented with CLA isomers or CLA isomer supplemented diets enriched in Se significantly increased $\Sigma$ CFA content in the liver compared with the control rats (Group 1) (the significant difference at the $\mathrm{P}<0.05$ level)

and Se (Groups $3_{+\mathrm{Se}}$ and $6_{+\mathrm{Se}}$ ) is considerably higher $(23.6-23.5 \%)$ than the percentage contribution of the original $t, t$ CLA isomers (10.1-9.7\%) in the liver of rats fed only the mixture of the CLA isomers (Groups 3 and 6).

The results of the experiment also demonstrated that accumulation of the $c 9, t 11$ and $t 10, c 12$ CLA isomers in the liver was selective (Groups 3 and 6) and clearly show that the percentage contribution of these isomers is relatively smaller in the liver lipids (i.e. 72.0 and $72.2 \%$ of the total amount of the CLA isomers) compared with their percentage contribution (79.6\%) in the dietary mixture of the CLA isomers. Of interest is the observation that Se in the diets enriched in 1 and $2 \%$ of mixture of CLA isomers (Groups $3_{+\mathrm{Se}}$ and $6_{+\mathrm{Se}}$ ) decreased the relatively content of the $c 9, t 11$ and $t 10, c 12$ CLA isomers in the liver (70.3 and 63.7\%) compared with their relative content ( 72.0 and $72.2 \%$, respectively) in the liver of rats fed only 1 and 2\% mixture of the CLA isomers (Groups 3 and 6).

The percentage contribution of the cis, cis $(c, c)$ CLA isomers within Groups 3 and 6 was similar ( 4.6 and $5.6 \%$, respectively) and practically equal to the percentage contribution of the $c, c$ CLA isomers in the dietary mixture of the CLA isomers (i.e. $5.2 \%$ of the total amount of CLA isomers), while the presence of Se 
in the diet enriched with the $2 \%$ mixture of CLA isomers (Group $6_{+\mathrm{Se}}$ ) resulted in a considerably higher percentage contribution of the $c, c$ CLA isomers in the liver $(10.7 \%)$.

Considering the above results, we could hypothesize that the $t, t$ CLA isomers are catabolized more slowly and are poor substrates for $\beta$-oxidation. Indeed, these isomers are incorporated into liver membrane phospholipids due to their geometrical configuration (Yang et al., 2002). On the other hand, the $c, t$ and $t, c$ CLA isomers are rapidly metabolized to form long-chain FAs containing conjugated double bounds (CFA), partly $\beta$-oxidized and, due to their unsuitable geometrical configuration, the $c, t$ and $t, c$ CLA isomers are less efficiently incorporated in to liver phospholipids. Recent studies (Igarashi and Miyazawa, 2000; Givens et al., 2001; Gnädig et al., 2002; Czauderna et al., 2003b) reinforce the finding that CLA isomers could be metabolized in vivo into long-chain conjugated PUFA (CFA) using the same pathway as linoleic acid. Therefore, these metabolites (i.e. cis-6,cis-9,cis-11C18:3, cis-6,trans-10, cis-12C18:3, cis-8,cis11,trans-13C20:3, cis-8,trans-12,cis-14C20:3, cis-5,cis-8,cis-11,trans-13C20:4 and cis-5,cis-8,trans-12,cis-14C20:4) (Czauderna et al., 2003b) possessing conjugated double bonds are easily UV-detected using the $\mathrm{Ag}^{+}$-HPLC system A and HPLC system B (Czauderna and Kowalczyk, 2002; Czauderna et al., 2003a). Consistently, our results also demonstrated that the concentration of CFA in the liver (Table 2) is always significantly higher in rats fed the CLA isomers (Groups 3-6) compared with the liver of the control rats (Groups 1). Moreover, the concentration of CFA in the liver showed a dose-response relationship (i.e. compare Groups 3 vs 6 and $3_{+\mathrm{Se}}$ vs $6_{+\mathrm{Se}}$; Table 2). Indeed, the $t 10, c 12$ and $c 9, t 11$ isomers are substrates for $\Delta 5$ - and $\Delta 6$-desaturases, so, after feeding the diet with the extra CLA isomers, conjugated eicosateraeoic acids were found in rat liver (Gnädig et al., 2001). Surprisingly, supplementation of the diet with only Se significantly increased $(\mathrm{P}<0.01)$ the level of CFA in the liver (Group $2_{+\mathrm{Se}}$ ). Thus, we suggest that the supplementation diet with only Se stimulated izomerization, elongation or/and desaturation of some fatty acids (e.g., linoleic or linolenic acid) in the liver, hence the concentration of CFA (Group 2 $2_{+\mathrm{Se}}$ ) was 7.7-fold higher in comparison with the CFA content in the liver of the control rats (Group 1). The presence of Se in the diet enriched in CLA isomers (Groups $3_{+\mathrm{Se}}$ and $6_{+\mathrm{Se}}$ ) also stimulated formation of CFA in comparison with the liver of rats fed only the CLA isomers (Groups 3-6).

As can be seen from the results in Table 2, Se in the diet enriched to the highest level of the CLA isomer mixture (Group $6_{+\mathrm{Se}}$ ) accelerated metabolism of these isomers and formation of CFA in the liver compared with liver metabolism of rats fed only the mixture of CLA isomers (Group 6). Based on the results summarized in Tables 2 and 3, we argue that in the presence of Se, the higher amount of the CLA isomers accumulated in the liver are metabolized to the long-chain fatty 
acids containing conjugated double bonds (CFA). A similar effect of Se in experimental diets was found in muscles of rats fed a diet supplemented with $\mathrm{Se}$ and a mixture of CLA isomers (Czauderna et al., 2003b). On the other hand, Se in the diets supplemented with a mixture of CLA isomers stimulated the formation of $t, t$ isomers (Groups $3_{+\mathrm{Se}}$ and $6_{+\mathrm{Se}}$ ) as well as decreased the rate of metabolism and/or $\beta$-oxidation of $t, t$ and $c, c$ CLA isomers in the liver.

In our studies, the concentration ratios of the $c 9, t 11$ CLA isomer to the $t 10, c 12$ CLA isomer in the liver of rats fed the diets enriched with the CLA isomer mixture were, regardless of the presence of Se, smaller compared with the ratio $\left(\mathrm{R}_{t 10, c 12 / c, t 11}\right)$ of these isomers in the CLA isomer mixture added to the diets (i.e. 0.712 - 0.833 vs 1.0242; see Table 3 ). Thus, our present results are in agreement with results of Alasnier et al. (2002) and our previous study (Czauderna et al., 2003b) in which the $t 10, c 12$ and $t 10, t 12$ CLA isomers were also more efficiently driven through $\beta$-oxidation in the cells of muscles, kidneys, adipose tissue or liver than their 9,11 homologues. In our investigation, the values of $\mathrm{R}_{t 10, c 12 / c, t 11}$ (Table 3) were higher in the liver of rats fed Se and the mixture of the CLA isomers (Groups $3_{+\mathrm{Se}}$ and $6_{+\mathrm{Se}}$ ) compared with the $\mathrm{R}_{t 10, c 12 / c, t 11}$ values in the liver of rats fed only the mixture of CLA isomers (Groups 3 and 6). Therefore, it can be hypothesized that dietary Se diminished the efficiency of $\beta$-oxidation of $t 10, c 12$ and $t 10, t 12$ CLA isomers in the liver.

\section{Fatty acid composition in the liver of rats fed the CLA isomers and selenium}

One of the most prominent effects of $1 \%$ dietary supplementation with a mixture CLA isomers and individual CLA isomers, regardless of the presence of Se in the diets (Groups 3, 4, 5, $3_{+\mathrm{Se}}, 4_{+\mathrm{Se}}$ and $5_{+\mathrm{Se}}$ ), is a reduction of the sum of all assayed total FA, SFA, PUFA, MUFA, mono-cis C18:1 as well as individual FA like lauric, myristic, palmitic, stearic, behenic, linoleic, oleic, and $\gamma$-linolenic acids in the liver (Tables 4 and 5). Feeding a diet supplemented only with Se (Group $2_{+\mathrm{Se}}$ ) resulted in a significant decrease in the deposition of the sum of all investigated FAs $(\mathrm{P}<0.01)$, also including trans-fatty acids and cis-6C18:1 $(\mathrm{P}<0.05$; Table 4). 


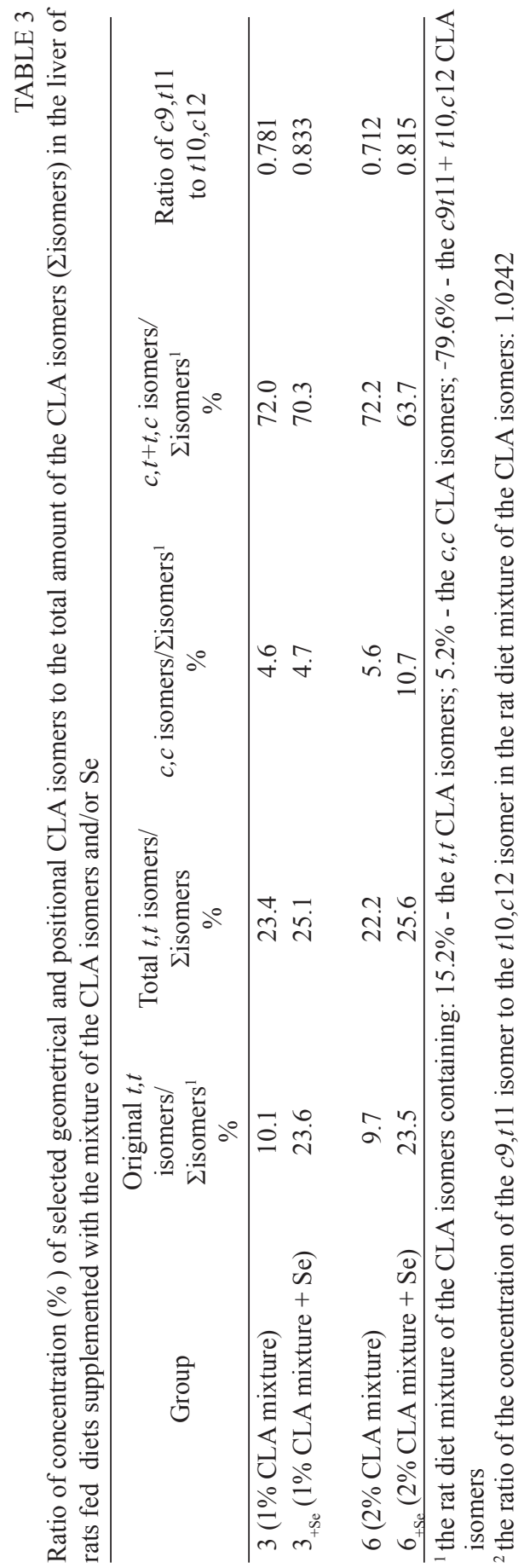




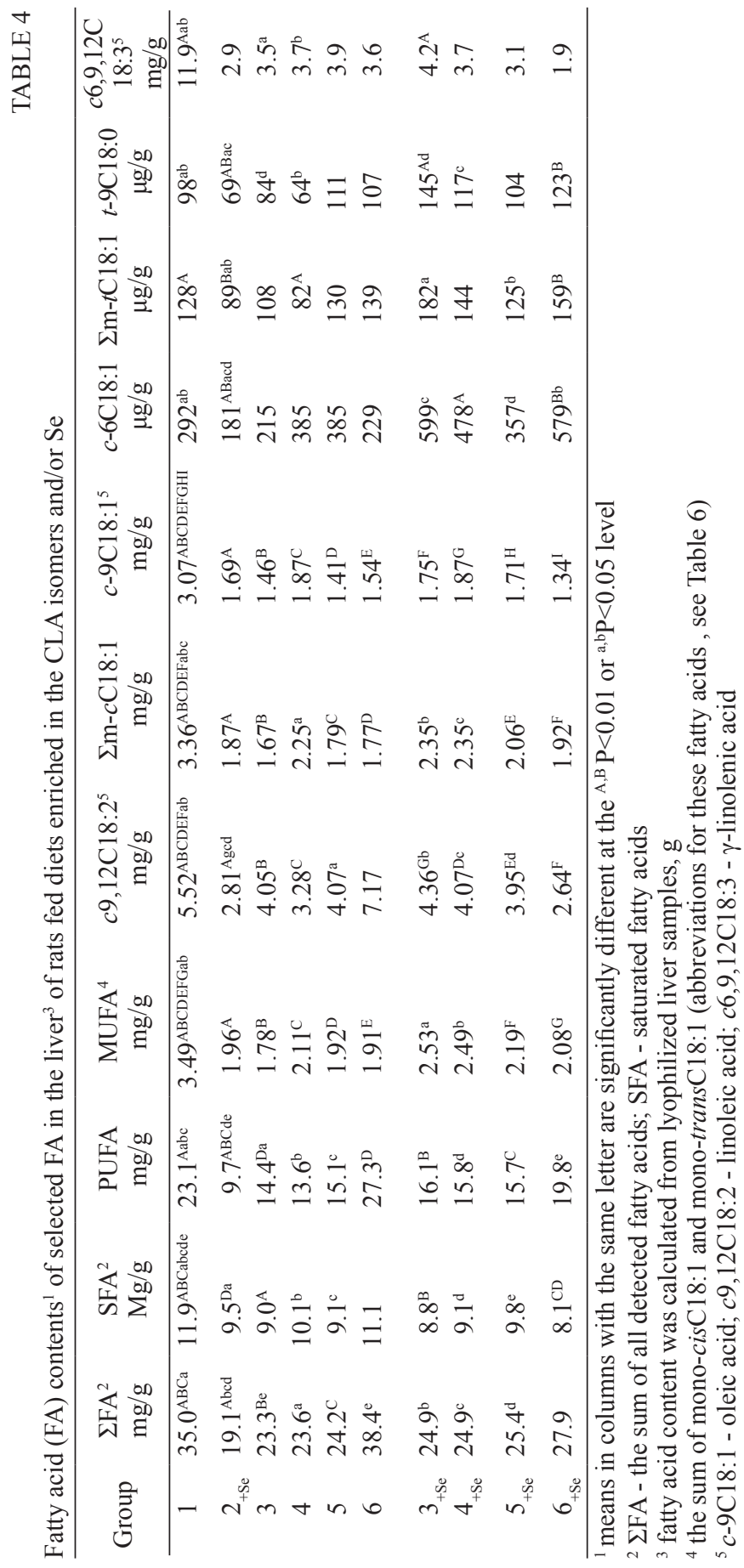


Se in the diet enriched in CLA isomers (Groups $3_{+\mathrm{Se}}, 4_{+\mathrm{se}}, 5_{+\mathrm{Se}}$ and $6_{+\mathrm{Se}}$ ) generally stimulated a decrease in the concentration of the sum of all assayed FAs in the liver, and increased the concentration of cis-6 C18:1 and assayed trans fatty acids (Table 4). So, it is clear that $\mathrm{Se}(\mathrm{VI})$, as a strong oxidant in the CLA-isomerenriched diets (Groups $3_{+\mathrm{Se}}, 4_{+\mathrm{Se}}, 5_{+\mathrm{Se}}$ and $6_{+\mathrm{Se}}$ ), stimulated formation of unsaturated FAs possessing a trans geometric configuration that is not typical of non-ruminants (Table 4). Unexpectedly, rats fed the mixtures of CLA isomers or individual isomers (regardless of the presence of Se in the diet) showed generally the higher concentration of C8:0 and C10:0 in the liver (Table 5). We could hypothesize that dietary supplementation of CLA isomers resulted in a decrease in all chain lengths of synthesized fatty acids, however this inhibitory effect was most pronounced for those synthesized de novo. On the other hand, de novo lipogenesis of fatty acids involves mainly short- and medium-chain length FAs (4-14 carbon atoms), and a portion of the 16-carbon fatty acids. So, these observations together suggest that in the liver of rats fed the experimental diets, the enhanced concentration of caprylic and capric acid (C8:0 and C10:0) could be related to stimulation of accumulation of FA $\beta$-oxidation products having longer carbon chains. The change in the concentration of arachidic acid (C20:0) in the liver (Table 5) could be correlated (Table 2) with the content change of CFA in the liver (i.e. long-chain CLA metabolites: cis-8,cis-11,trans-13C20:3, cis-8,trans-12,cis-14 C20:3, cis-5,cis8,cis-11, trans-13C20:4, cis-5,cis-8,trans-12,cis-14C20:4). So, we suggest that in the liver, some long-chain CLA metabolites might have been saturated before ( $\beta$-oxidation), consequently the content of arachidic acid depended upon the concentration of long-chain CLA metabolites (CFA).

Feeding the CLA isomers, regardless of the presence of dietary Se, resulted in decreasing the content of oleic acid (cis-9C18:1) and the sum of mono-cis C18:0 in the liver. This is consistent with our previous results (Czauderna et al., 2003b) showing that CLA isomers, especially the $t 10, c 12$ CLA isomer, are responsible for the change in the levels of mono-unsaturated and saturated FAs in organs from animals fed the CLA isomers due to decreasing the $\Delta 9$ desaturation of FAs such as C16:0 or C18:0 (Alasnier et al., 2002). Recent studies (Alasnier et al., 2002; Bauman et el., 2003) have demonstrated that CLA isomers, especially the $t 10, c 12$ CLA isomer, caused a reduction in $\triangle 9$-desaturase capacity, inhibited steaoryl-CoA desaturase mRNA expression and FA synthesis. Consequently, the value of the concentration ratio $(\mathrm{R})$ of oleic acid to $\mathrm{C} 18: 0$ (i.e. $\Delta 9$-desaturase index) in the liver of rats fed the experimental diets increased (Table 6) compared with the concentration ratio of these fatty acids in the liver of the control rats (Group 1). Recent studies (Simon et al., 2000; Alasnier et al., 2002; Bauman et al., 2003) have found that after CLA isomers (especially the trans-10, cis-12 isomer) were fed to mice, the content of stearyl-CoA desaturase gene $1 \mathrm{mRNA}$ in the liver decreased by $45-75 \%$. Thus, a decrease in $\Delta 9$-desaturation is a major reason for modification 


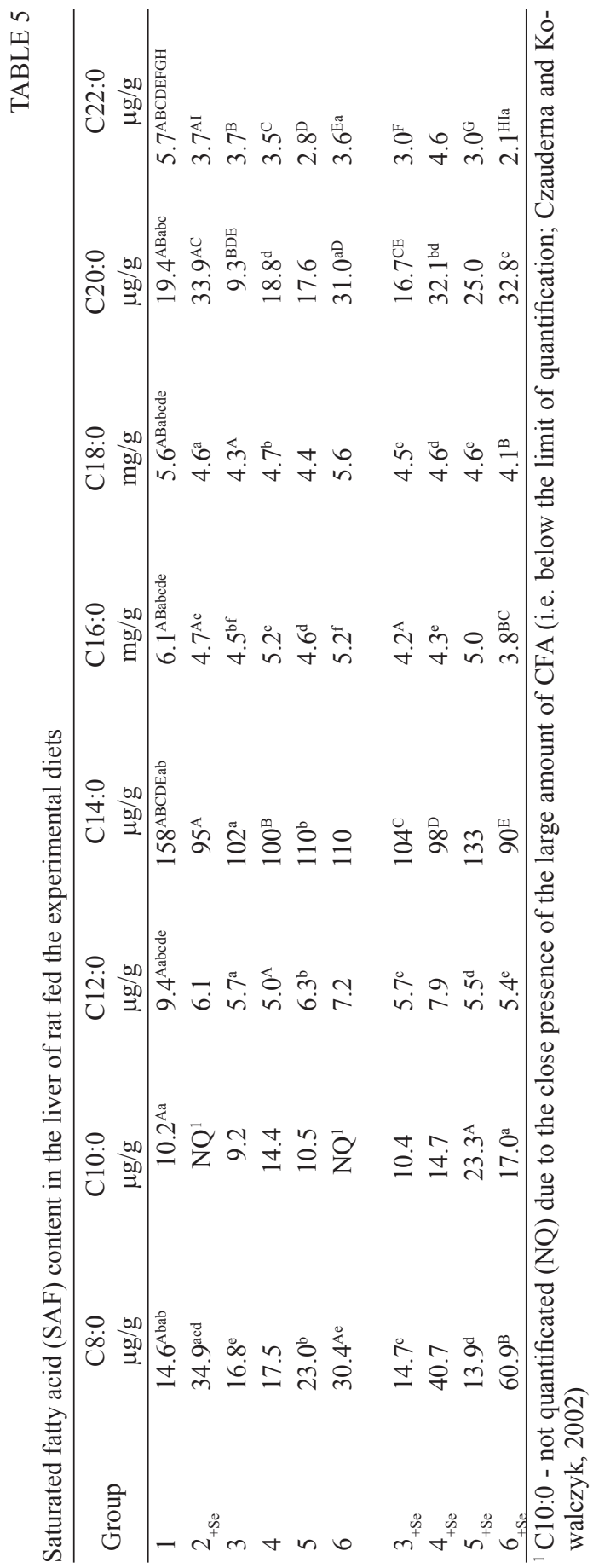


递

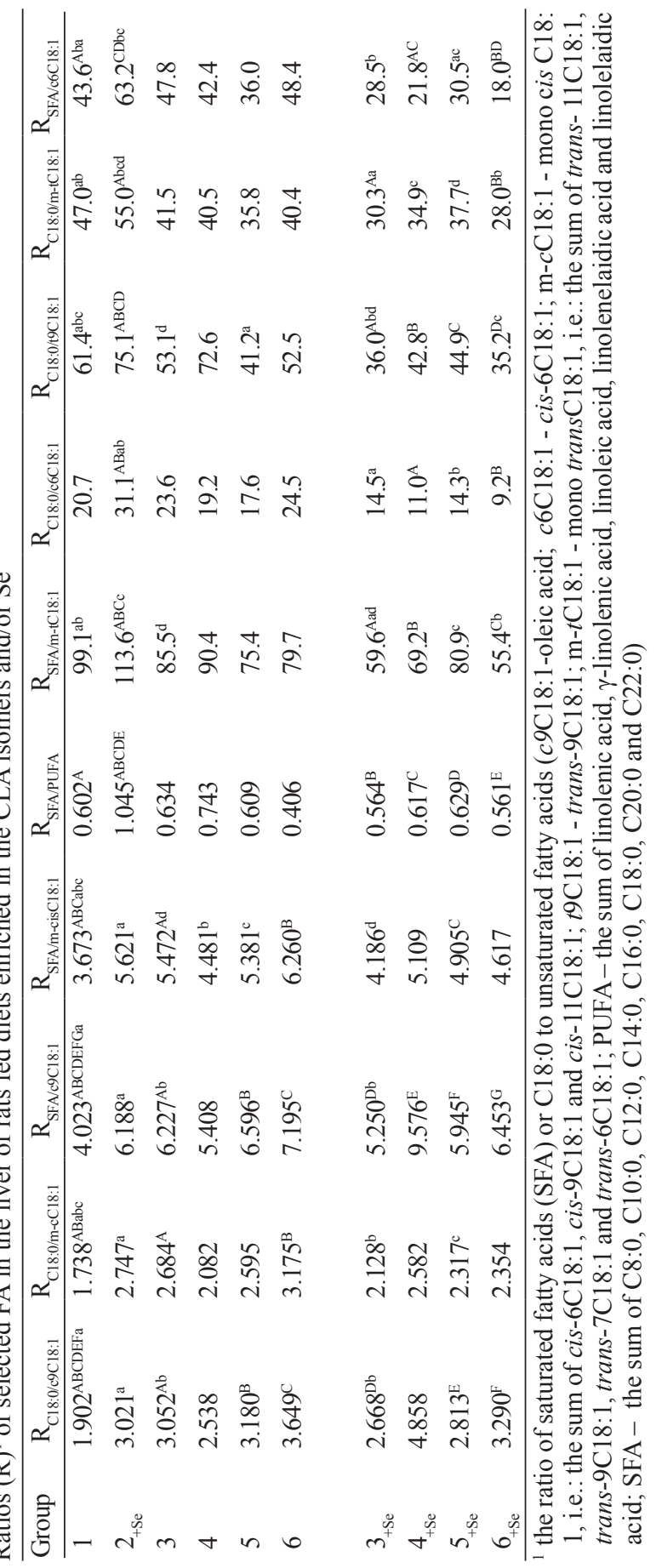


of the FA profile in animals fed CLA isomers (Simon et al., 2000). The substrate: product relationship for $\Delta$ 9-desaturase is further supported by detailed analysis of values of the $\mathrm{R}_{\mathrm{C} 18: 0 / \mathrm{m}-c \mathrm{C} 18: 1}, \mathrm{R}_{\mathrm{SFA} / c 9 \mathrm{C} 18: 1}$ and $\mathrm{R}_{\mathrm{SFA} / \mathrm{m}-\mathrm{cis} \mathrm{C} 18: 1}$ ratios (Table 6). As shown in Table 5, CLA isomers and Se in the diet inhibited $\Delta 6$-desaturase activity, and this effect was predominantly seen for $\gamma$-linolenic acid in all of the experimental diets (i.e. generally for formation n-6 PUFA). On the other hand, the substrate:product relationship for the $\mathrm{R}_{\mathrm{C} 18: 0 / / 6 C 18: 1}, \mathrm{R}_{\mathrm{C} 18: 0 / 9 \mathrm{C} 18: 1}, \mathrm{R}_{\mathrm{SFA} / c 6 \mathrm{C} 18: 1}, \mathrm{R}_{\mathrm{C} 18: 0 / \mathrm{m}-\mathrm{C} C 18: 1}, \mathrm{R}_{\mathrm{SFA} / \mathrm{PUFA}}$ and $\mathrm{R}_{\mathrm{SFA} / \mathrm{m}-\mathrm{C} \mathrm{C} 18: 1}$ ratios was not consistent, so, we suppose that the experimental diets decreased both the formation yield of substrates for $\Delta 9$-, $\Delta 6$ - and/or $\Delta 5$-desaturase and the capacity of these desaturases.

\section{CONCLUSIONS}

We conclude that at $2 \mathrm{ppm}$ Se supplementation was of no benefit for rat body mass gain, however, it was safe. Our experiment demonstrated that Se (VI), as a strong oxidant, stimulated driving SFA and PUFA through the $\beta$-oxidation pathway. Feeding 1\% CLA isomers, regardless of the presence of Se, resulted generally in decreasing the concentration of all assayed non-conjugated fatty acids. The current study clearly showed that trans-trans CLA isomers are preferentially incorporated into the liver while there is partial discrimination in the accumulation of cis-cis and cis-trans/trans-cis CLA isomers. The lower concentration of cis-cis and trans-cis/cis-trans CLA isomers (like trans-10,cis-12 isomer) is the result of rapid metabolism, $\beta$-oxidation and poor geometrical configuration. On the other hand, the higher concentration of trans-trans CLA isomers could be due to their slower metabolism, preferred geometrical insertion into membrane phospholipids, and the fact that they are poor substrates for the $\beta$-oxidation pathway (Yang et al., 2002). The results clearly demonstrate that the CLA isomer content in the liver reflected that of dietary CLA and Se. CLA isomers, specifically the trans-10,cis-12 CLA isomer, are a potent inhibitor of fat synthesis and these isomers were responsible for the modification of the saturation/mono-unsaturation ratio by decreasing the $\Delta 9$-desaturation of $\mathrm{C} 16: 0$ and $\mathrm{C} 18: 0$. 


\section{REFERENCES}

Alasnier C., Berdeaux O., Chardigny J.M., Sébédio J.L., 2002. Fatty acid composition and conjugated linoleic acid content of different tissues in rats fed individual conjugated linoleic acid isomers given as triacylglycerols. J. Nutr. Biochem. 13, 337-345

Arteel G.E., Sies H., 2001. The biochemistry of selenium and gluthatione system. Environ. Toxicol. Pharmacol. 10, 153-158

Bauman D.E., Corl B.A., Peterson D.G., 2003. The biology of conjugated linoleic acids in ruminants. In: J.L. Sebedio, W.W. Christie, R.O. Adlof (Editors). Advances in Conjugated Linoleic Acid Research. AOCS Press, Champagign, Illinois, vol. II, pp. 146-173

Corino C., Mourou J., Magni S., Pastorelli G., Rosi F., 2002. Influence of dietary conjugated linoleic acid on growth, meat quality, lipogenesis, plasma leptin and physiological variables of lipid metabolism in rabbits. J. Anim. Sci. 80, 1020-1028

Crespo A.M., Reis M.A., Lanca M.J., 1995. Effect of selenium supplementation on polyunsaturated fatty acids in rats. Biol. Trace Elem. Res. 47, 335-341

Czauderna M., Kowalczyk J., 2002. Separation of some mono-, di- and tri-unsaturated fatty acids containing 18 carbon atoms by high-performance liquid chromatography and photodiode array detection. J. Chromatogr. B 760, 165-178

Czauderna M., Kowalczyk J., 2002. HPLC sepatration of some unsaturated and saturated fatty acids. Chem. Anal. (Warszawa) 47, 867-882

Czauderna M., Kowalczyk J., Wąsowska I., Niedźwiedzka K.M., 2002. A highly efficient method for derivatization of fatty acids for high performance liquid chromatography. J. Anim. Feed Sci. $11,517-526$

Czauderna M., Kowalczyk J., Wąsowska I., Niedźwiedzka K.M., 2003a. Determination of conjugated linoleic acid isomers by liquid chromatography and photodiode array detection. J. Anim. Feed Sci. 12, 269-382

Czauderna M., Kowalczyk J., Wąsowska I., Niedźwiedzka K.M., Pastuszewska B., 2003b. The effects of selenium and conjugated linoleic acid (CLA) isomers on fatty acid composition, CLA isomer content in tissues, and growth of rats. J. Anim. Feed Sci. 12, 865-881

Czauderna M., Kowalczyk J., Wąsowska I., Niedźwiedzka K.M., Pastuszewska B., 2004. Conjugated linoleic acid (CLA) content and fatty acids composition of muscle in rats fed isomers of CLA and selenium. J. Anim. Feed Sci. 13, 183-196

Degrace P., Demizieux L., Gresti J., Chardigny J., Sébédio J., Clouet P., 2003. Association of liver steatosis with lipid oversecretion and hypotriglyceridaemia in C57BL/6j mice fed trans-10,cis-12-linoleic acid. FEBS Lett. 546, 335-339

Givens D.I., Cottroll B.R., Davies M., Lee P.A., Mansbridge R.J., Moss A.R., 2001. Sources of n-3 polyunsaturated fatty acids additional to fish oil for livestock diets - a review. Nutr. Abstr. Rev., Ser. B. 71, 54R-83R

Gnädig S., Rickert R., Sébédio J.L., Steinhart H., 2001. Conjugated linoleic acid (CLA): physiological effects and production. Eur. J. Lipid Sci. Tech. 103, 56-61

Igarashi M., Miyazawa T., 2000. Do conjugated eicosapentaenoic acid and conjugated decosahexaenoic acid induce apoptosis via lipid peroxidation in cultured human tumor cells? Biochem. Bioph. Res. Co. 270, 649-656

Madrom M.S., Peterson D.G., Dwyer D.A., Corl B.A., Baumgard L.H., Beermann D.H., Bauman D.E., 2002. Effect of extruded full-fat soybeans on conjugated linoleic acid content of intramuscular, intermuscular, and subcutaneous fat in beef steers. J. Anim. Sci. 80, 1135-1143

Nagao K., Wang Y., Inoue N., Han S., Buang Y., Noda T., Kouda N., Okamatsu H., Yanagita T., 2003. The 10trans, 12cis izomer of conjugated linoleic acid promotes energy metabolim in OLETF rats. Nutrition $19,652-656$ 
Rahman S.M., Wang Y.M., Yotsumoto H., Cha J.Y., Han S.Y., Inoue S., Yanagita T., 2001. Effects of conjugated linoleic acid on serum leptin concentration, body-fat accumulation, and $\beta$-oxidation of fatty acid in OLETF rats. Nutrition 17, 385-390

Sakono M., Miyanaga F., Kawahara S., Yamauchi K., Fukuda N., Watanabe K., Iwata T., Sugano M., 1999. Dietary conjugated linoleic acid reciprocally modifies ketogenesis and lipid secretion by the rat liver. Lipids 34, 997-1000

Simon O., Männer K., Schäfer K., Sagredos A., Eder K., 2000. Effects of conjugated linoleic acids on protein to fat proportions, fatty acids, and plasma lipids in broilers. Eur. J. Lipid Sci. Tech. $102,402-410$

Szymczyk B., Pisulewski P., Szczurek W., Hanczakowski P., 2000. The effects of feeding conjugated linoleic acid (CLA) on rat growth performance, serum lipoproteins and subsequent lipid composition of selected rat tissues. J. Sci. Food Agr. 80, 1553-1558

Tapiero H., Townsend D.M., Tew K.D., 2003. The antioxidant role of selenium and seleno-compounds. Biomed. Pharmacother. 57, 134-144

Terpstra A.H.M., 2003. Fat and energy metabolism. An overview of the literature. Department of Laboratory Animal Science, Utrecht University Press, Utrecht (The Netherlands)

West D.B., DeLany J.P., Camet P.M., Blohm F., Truett A.A., Scimeca J., 1998. Effects of conjugated linoleic acid on body fat and energy metabolism in the mouse. Amer. J. Physiol. Regul. Integr. C 275, R667-R672

Wolffram S., 1999. Absorption and metabolism of selenium: differences between inorganic and organic sources. In: T.P. Lyons, K.A. Jacques (Editors). Biotechnology in the Feed Industry. Nottingham University Press, pp. 547-566

Wysocka I.A., Bulska E., Wróbel K., 2003. A comparison of electrothermal atomic absorption spectrometry and inductively coupled plasma mass spectrometry for the determination of selenium in garlic. Chem. Anal. (Warszawa) 48, 919-929

Yang L., Yeung S.Y.V., Huang Y., Wang H.Q., Chen Z.Y., 2002. Preferential incorporation of trans, trans-conjugated linoleic acid isomers into the liver of suckling rats. Brit. J. Nutr. 87, 253-260

\section{STRESZCZENIE}

\section{Wpływ dodatku selenu oraz izomerów sprzężonego kwasu linolowego (CLA) do diety na masę wątroby i wzrost szczurów oraz zawartość CLA i innych kwasów tluszczowych w wątrobie}

Badano wpływ dodatku selenu ( $j a k o \mathrm{Na}_{2} \mathrm{SeO}_{4}$ ) i/lub izomerów sprzężonego kwasu linolowego (CLA) na przyrost masy wątroby i ciała szczurów oraz stężenie izomerów CLA i innych kwasów thuszczowych w wątrobie. Dodatek Se i/lub CLA nie spowodował istotnych zmian w przyrostach masy ciała oraz wątroby. Podawanie szczurom izomerów CLA zwiększyło istotnie ich stężenie oraz zawartość innych kwasów thuszczowych zawierających podwójne sprzężone wiązania (CFA) w wątrobie. Dodatek Se do diety zawierającej izomery CLA stymulował gromadzenie się izomerów CLA i CFA w wątrobie. Badania wykazały, że izomery trans-trans izomery CLA są wolniej katabolizowane i preferowane jako substraty w procesie ß-oksydacji. Izomery cis-trans/trans-cis są szybko metabolizowane, a w wyniku tego tworzą się długołańcuchowe CFA. Bez względu na obecność Se w diecie zawierającej 1\% mieszaniny CLA lub 1\% poszczególnych izomerów CLA zmniejszyła się całkowita zawartość oznaczonych kwasów tłuszczowych, nasyconych kwasów tłuszczowych, PUFA oraz MUFA. Wyniki badań wskazuja, że podawanie diet zawierających CLA, niezależnie od dodatku Se, zmniejszyło aktywność $\Delta 9$-desaturazy i ekspresję mRNA stearylo-CoA desaturazy oraz hamowało syntezę kwasów thuszczowych, co spowodowało, że wartość stosunku stężeń kwasu oleinowego do C18:0 (indeks $\Delta$ 9-desaturazy) wzrasta w wątrobie szczurów żywionych dietami z dodatkiem izomerów CLA. 